\title{
PEMERIKSAAN FESES UNTUK IDENTIFIKASI CACING DAN AMOEBA PADA SANTRI DI PONDOK PESANTREN
}

\author{
Luh Titi Handayani \\ Dosen Prodi S1 Keperawatan Fakultas Ilmu Kesehatan UM Jember \\ Email : luhtiti@unmuhjember.ac.id
}

\begin{abstract}
Islamic boarding school has excesive activity within 24 hours and become a house for living for the students. Crowded environment at islamic boarding school emerging a possibility of communicable disease such as scabies and gastrointestinal disorder. The purpose of this study is to identify the student's health at islamic boarding school through the infection of amoeba and helminths in their feses. It's a non experimental reasearch. There were 30 respondents taking part of this research and the sample are taken from instant stool sample. The results show that $46,7 \%$ respondents have positive 2 results. It means that there were infection and parasite living in their gastrointestinal tract. The role of clean and healhty behavioral pattern (PHBS) are very important in islamic boarding school environment and it implementation need an integrated role of every part of islamic boarding school such as student, executive organizer and health care worker. The role of kyai and ustadz (teacher) as the role model for the students are needed in order to give the example of implementation of clean and healhty behavioral pattern form health and Islamic perspective
\end{abstract}

Keywords : gastrointestinal disorder, amoeba and helminths, Islamic boarding school

\section{PENDAHULUAN}

Pesantren dalam arti kata berasal dari kata tempat para santri. Pesantren dalam istilah dikenal dengan pondok yang mempunyai kamar dan ruang kecil dengan kesederhanaan bangunan, tempat di mana para santri belajar tentang ilmu agama kepada para guru dan kyai. Pada perkembangannya setelah merdeka pondok tradisional sudah mengalamai modernisasi baik dari keilmuan, visi, misi dan bangunan. Pondok pesantren modern banyak berdiri dengan segala fasilitasnya yang lebih baik tetapi pondok pesantren tradisional dengan segala keterbatasan dan kekurangan juga masih banyak berdiri. Pondok pesantren terutama yang tradisional masih banyak yang menerapkan kultur budaya tradisional (Rosmila, 2013).

Kehidupan pondok yang padat huni dengan kegiatan harian yang padat. Kehidupan di pondok tidak jauh dengan sekolah biasa, tetapi kebanyakan dari santri pondok pesantren hidup bersama dalam satu tempat. Dampak dari tinggal bersama dan dalam waktu yang lama dengan jumlah santri yang cukup banyak akan mempunyai dampak, salah satunya terhadap masalah kesehatan. Perilaku hidup bersih dan sehat (PHBS) dalam pondok pesantren sangat diperlukan. PHBS diperlukan untuk kesehatan para santri untuk menekan faktor risko terkena dan tertular penyakit dan meningkatkan keberlangsungan lingkungan yang sehat. Para santri dan pengelola diperlukan kerjasama dalam menjaga kebersihan baik kebersihan diri ataupun kebersihan lingkungan (Elizabeth, 2017). Hasil penelitian yang dilakukan oleh (Syam, Gafur, \& Hamzah, 2018) menyatakan bahwa hasil wawancara dengan responden yang terdiri dari pengelola, santri dan masyarakat sekitar yang menjadi permasalahan adalah gangguan kesehatan, sanitasi lingkungan pemukiman, personal hygiene, gizi keluarga dan sarana pendukung poskestren.

Hasil kegiatan penelitian dan pengabdian kepada masyarakat (PKM) yang dilakukan oleh 
Syam, Gafur \& Hamzah (2018) menyebutkan bahwa gangguan kesehatan yang sering timbul di Pesantren adalah sebagian besar penyakit gatal dan scabies (90\%), batuk pilek, demam, sesak nafas dan gastritis. Menurut teori H.L Bloom ada empat faktor yang mempengaruhi derajad kesehatan : 1) faktor lingkungan, 2) perilaku, 3) pelayanan kesehatan dan 4) keturunan. Faktor lingkungan merupakan faktor dominan diikuti perilaku, fasilitas kesehatan dan keturunan. Lingkungan berhubungan dengan lingkungan fisik seperti sampah, air limbah, udara, tanah, ikim, perumahan, dan sebagainya.

Dampak dari personal hygiene, lingkungan dan sanitasi serta status gizi yang kurang baik akan berdampak pada gangguan pencernaan. Dalam hal ini peneliti melakukan penelitian tentang identifikasi status kesehatan pencernaan melalui hasil dari pemeriksaan feses pada santri pondok pesantren tradisional (Suharmanto, 2015).

Pondok Pesantren adalah tempat umum yang didalamnya terdapat para santri yang tinggal dengan aktivitas sehari-hari selama hampir 24 jam setiap harinya. Rutinitas yang padat dengan keterbasan fasilitas dan PHBS yang tidak baik dapat menimbulkan belbagai macam gangguan, seperti penyalit kulit scabies, penyakit ganggun sistem percernaan. Penyakit yang disebabkan oleh air atau waterborne disease. Air merupakan media yang baik sebagai tempat tinggal belbagai bibit penyakit dan salah satunya adalah diare. Kondisi lingkungan yang kurang bersih akibat terkontaminasi E coli dalam air bersih. Faktor lingkungan, kebiasaan mandi di sungai, dan kegiatan mandi cuci kakus (MCK) di sungai menjadi penyebab utama hygiene sanitasi perorangan yang tidak sehat (Akmal, Semiyarti, \& Gayatri, 2013).

\section{METODOLOGI PENELITIAN}

Disain penelitian adalah non eksperimental dengan deskriptif analitik. Populasi dan sampel adalah santri di Pondok Pesantren Miftahul Hasan Gunung Spikul Pakusari Jember. Jumlah sampel sebanyak 30 responden yang dipilih dengan cara simple random sampling. Tujuan penelitian adalah untuk mengidentifiksai sistem pencernaan dengan melihat hasil uji laboratorium feses secara mikroskopik terhadap telur cacing dan amoeba. Teknik pengambilan sampel feses diambil pada setiap responden yang dilakukan pada Juni 2018 .

\section{HASIL DAN PEMBAHASAN}

\section{1) Umur}

\section{Tabel 1. Distribusi Frekuensi Umur}

\begin{tabular}{ccc}
\hline Umur & Frekuensi & $\begin{array}{c}\text { Persentase } \\
(\%)\end{array}$ \\
\hline 12-14 tahun & 9 & $30 \%$ \\
15-19 tahun & 21 & $70 \%$ \\
\hline Total & 30 & $100 \%$ \\
\hline
\end{tabular}

Bedasarkan tabel 1 didapatkan responden terbanyak berusia 15-19 tahun sebanyak $70 \%$ (21/30).

Umur yaitu usia individu yang terhitung mulai saat dilahirkan sampai berulang tahun di tahun 2018, semakin cukup umur, tingkat kematangan dan kekuatan seseorang akan lebih matang dalam berfikir dan bekerja.

Hasil penelitian (Zakiudin \& Zhaluhiyah, 2016) menyatakan bahwa korelasi antara usia dan PHBS didapatkan uji statistik chi square dengan $\mathrm{p}$ value $=0,232$ yang artinya tidak ada beda usia dalam perilaku PHBS dalam penelitian, juga berarti data sampel berdistribusi normal. Notoatmojo (2003) menyatakan bahwa umur mempengaruhi daya tangkap dan pola pikir seseorang. Harapannya semakin bertambah umur akan bertambah ilmu pengetahuannya.

\section{2) Pendidikan}

Tabel 2. Distribusi Frekuensi pendidikan

\begin{tabular}{ccc}
\hline $\begin{array}{c}\text { Jenis } \\
\text { kelamin }\end{array}$ & Frekuensi & Persentase (\%) \\
\hline SMP & 23 & $76.6 \%$ \\
SMK & 7 & $23.3 \%$ \\
\hline Total & 30 & $100 \%$
\end{tabular}

Berdasarkan tabel 2 didapatkan persentasi terbanyak adalah yang berpendidikan SMP sebanayk 76,6\% (23/30). 
Pendidikan merupakan faktor internal yang mempengaruhi pola berfikir terhadap ilmu pengetahuan (Notoadmojo, 2010). Pendidikan, akan didapat informasi belbagai ilmu pengetahuan sehingga dapat meningkatkan kualitas hidup. Hasil penelitian ini, tingkat pendidikan terbanyak adalah SMP, sehingga berkontribusi untuk lebih meningkatkan dalam mengatur dan memotivasi perilaku. Pendidikan dapat memperbarui dengan belbagai informasi, sehingga diharapkan akan semakin baik perilakunya di dalam bidang kesehatan.

3) Perilaku Hidup Bersih dan sehat (PHBS) Tabel 3. Distribusi PHBS

\begin{tabular}{ccc}
\hline PHBS & Frekuensi & Persentase (\%) \\
\hline Cukup & 26 & $86.7 \%$ \\
Baik & 4 & $13.3 \%$ \\
\hline Total & 30 & $100 \%$
\end{tabular}

Bedasarkan tabel 3 didapatkan persentase terbanyak adalah PHBS dengan kategori cukup sebanyak $86,7 \%$ (26/30).

PHBS adalah perilaku sehat dan berperan aktif dalam menolong diri sendiri dan orang di sekitarnya (Depkes, 2007). Peningkatan PHBS membutuhkan interaksi antar individu dan kelompok dalam mempertahankan derajad kesehatan yang optimal. PHBS juga tidak terlepas dari pendidikan dan pengetahuan. PHBS sebagai tahap akhir setelah seseorang mampu menambah pengetahuan baik secara formal dan informal melalui pengamatan, kemudian akan membentuk sikap dan pernyataan dan kemudian akan dilaksanakan sebagai sebuah perilaku. Harapan dari penelitian ini adalah ada korelasi sinergis antara pengetahuan, sikap dan perilaku, sehingga sikap hidup terhadap perilaku akan lebih baik (Notoadmojo, 2010).

Menurut Notoatmojo (2010) dalam ilmu perilaku bahwa pengetahuan dan perilaku akan dipengaruhi oleh faktor eksternal seperti lingkungan dan budaya. Jika kehidupan lingkungan dan budaya PHBS masyarakat santri di pondok pesantren baik, maka akan memberikan efek yang baik juga pada sekitarnya. sehingga dengan diperolehnya PHBS dari hasil penelitian ini adalah cukup, maka masih diperlukan tatanan yang baik untuk melestarikan lingkungan dan budaya PHBS yang baik tersebut.

\section{4) Kesehatan sistem pencernanan berdasarkan pemeriksaan telur cacing dalam feses}

Tabel 4 Distribusi Kesehatan sistem pencernanan berdasarkan pemeriksaan telur cacing pada feses

\begin{tabular}{ccc}
\hline $\begin{array}{c}\text { Hasil Feses } \\
\text { Lengkap } \\
\text { (hookworm) }\end{array}$ & Frekuensi & $\begin{array}{c}\text { Persentase } \\
(\%)\end{array}$ \\
\hline $\begin{array}{c}\text { Negatip } \\
\text { Positip }\end{array}$ & 0 & 0 \\
\hline Total & 30 & 100 \\
\hline
\end{tabular}

Hasil dari tabel 4 menyatakan bahwa hasil penelitian ini seluruh responden (100\%) terinfeksi telur cacing (hookworm), berarti kebersihan lingkungan dan hygiene perorangan sangat kurang baik. Dalam mencari penyebab responden terinfeksi telur cacing jenis hookworm (cacing tambang) ini, perlu mengetahui cara penularannya. Parasit nematoda ini masuk dan hidup dalam usus halus yang masuk melalui soil transmitted helminth / STH dari sayuran yang dicuci kurang bersih, sehingga masih mengandung air dan tanah yang telah terkontaminasi telur cacing ketika dimakan. Jadi sebagai tindak lanjut pencegahannya, sedapat mungkin sayuran dicuci bersih, sebelum dimakan mentah. Air juga dapat sebagai media dalam transmisinya.

Parasit Necator americanus termasuk organisme yang merugikan, karena dalam hidup nya membutuhkan makhluk hidup lain sebagai sumber makanan. Parasit dalam tubuh sangat merugikan, sehingga dapat menyebabkan kematian. Salah satu akibat yang disebabkan oleh parasit jenis cacing tambang adalah kurang gizi dan anemia. Santri di pondok pesantren yang terinfeksi telur cacing tambang, akan mengambil nutrisi yang dibutuhkan oleh tubuh juga 
metabolisme dari parasit tersebut, sehingga tubuh inangnya akan menjadi lemah dan sakit. Badan yang lemah oleh cacing dapat menyebabkan kerentanan terhadap berbagai penyakit seperti infeksi saluran pernafasan atas (ISPA) dan diare (Irmayanti, 2013).

Perkembangan telur hingga menjadi larva yang infektif membutuhkan waktu sekitar tujuh hari. Hal tersebut dapat dicegah dengan sering melakukan cuci tangan secara berkala guna menjaga kebersihan, terutama mencuci tangan sebelum makan dan setelah dari toilet dan kamar mandi, selalu menggunakan alas kaki dan hati-hati dalam mengkonsumsi sayuran mentah.

\section{5) Kesehatan sistem pencernanan berdasarkan pemeriksaan Amoeba dalam Feses}

Tabel 5 Distribusi Kesehatan sistem pencernanan berdasarkan pemeriksaan Amoeba pada Feses

\begin{tabular}{ccc}
\hline $\begin{array}{c}\text { Hasil Feses } \\
\text { Lengkap } \\
\text { (Amoeba) }\end{array}$ & Frekuensi & $\begin{array}{c}\text { Persentase } \\
(\%)\end{array}$ \\
\hline Negatip & 7 & 23,3 \\
Positip & 23 & 76,7 \\
\hline Total & 30 & $100 \%$ \\
\hline
\end{tabular}

Hasil dari tabel 5 menyatakan bahwa persentase positif amoeba terbanyak 76,7\% responden terinfeksi oleh amoeba. Pemeriksaan mikroskopis protozoa/amoeba merupakan pemeriksaan sistem pencernaan yang penting. Pada hasil penelitian ini pemeriksaan mikroskopik amoeba adalah terbanyak, hal ini menandakan hampir sebagian besar siswa menderita infeksi saluran cerna.

Sistem pencernaan dimulai dari mulut sampai anus yang berfungsi dalam mengolah makanan yang masuk secara fisik dan kimia sampai terjadi proses ekskresi, sekresi, abosrobsi dan reabsorbsi dari bahan makanan tersebut. Didalam sistem pencernaan terdapat bakteri normal (flora normal) yang membantu dalam proses pembusukan sisa makanan yang tidak diserap usus untuk menjadi feses (Anorital \& Andayasari, 2015).

Proses dalam sistem pencernaan tidak terlepas dari konsep fecal oral. Segala sesuatu yang masuk ke dalam mulut (oral), jika tidak terkontaminasi oleh bakteri tidak akan menimbulkan efek yang merugikan dalam tubuh. Ada beberapa faktor internal dan ekternal yang dapat menyebabkan sakit dalam sistem pencernaan. Faktor eksternal antara lain kebersihan makanan dan lingkungan, PHBS. Faktor internal seperti sistem kekebalan dan penyakit (Anorital \& Andayasari, 2015).

Hasil analisis data Riset Kesehatan Dasar (Riskesdas) tahun 2007, menunjukkan secara nasional masih rendahnya kualitas kesehatan dan perilaku tidak sehat pada masyarakat. Tindakan responden yang selalu mencuci tangan memakai sabun setelah BAB dan BAK hanya 31,6\%, sedangkan responden yang kadang-kadang cuci tangan pakai sabun setelah BAB dan BAK sebesar 63,2\% (Ali, 2017).

Kepercayaan dan tradisi sub kultur sejak awal berdirinya pondok pesantren menjadi perilaku yang turun menurun pada setiap generasi ditambah dengan fasilitas yang kurang dan tidak memperhatikan sanitasi lingkungan yang sehat. Perilaku mencontoh para kyai dan guru adalah bagian dari tradisi sub kultur (Hidayat, 2010).

\section{KESIMPULAN}

Berdasarkan hasil penelitian dan pembahasan didapatkan bahwa sistem pencernaan santri sebagian besar terinfeksi oleh amoeba dan telur cacing. Infeksi parasit (cacing tambang) dan amoeba adalah penyebab utama gangguan kesehatan sistem pencernaan di mana tanpa disadari gangguan ini dapat menyebabkan penyakit sistem pencernaan seperti diare, disentri dan kurang gizi. Dalam memutus mata rantai penularan dan pencegahan terinfeksi parasit dan amoeba yang utama adalah dengan meningkatkan PHBS dan juga melengkapi fasilitas dan perbaikan sarana seperti sarana air bersih yang memadai dan pembuangan limbah lingkungan dan MCK yang baik. 
PHBS santri di pondok pesantren perlu ditingkatkan baik dari kemauan dan kemampuan. Merubah cara pandang dan paradigma santri di pondok pesantren diperlukan suatu komitmen oleh semua yang terlibat dalam penentuan kebijakan pondok pesantren. Peran pengelola sangat diperlukan dalam menegakkan PHBS dari sisi kesehatan dan agama. Peran dari pihak manajemen pondok juga perlu ditingkatkan dari kinerja internal dan ekternal. Peran kerja sama ini, seperti bekerja sama dalam melakukan kegiatan penyuluhan kesehatan, survey fasilitas dan lingkungan, serta melakukan pemeriksaan berkala kepada seluruh penghuni pondok pesantren. Dengan harapan dapat memutus mata rantai penularan penyakit di lingkungan pondok pesantren (Ahmad, 2014).

Tradisi sub kultur dalam pondok pesantren juga harus dicetuskan dari seorang kyai atau ustad, seperti memberikan contoh dalam perilaku PHBS yang baik, sehingga kedepannya akan selalu digunakan sebagai panutan oleh seluruh santri.

\section{UCAPAN TERIMA KASIH}

Pada kesempatan ini penulis menyampaikan ucapan terima kasih kepada:

1. Dekan atas ijinnya untuk melakukan penelitian

2. Pimpinan Pondok Pesantren Miftahul Hasan Gunung Spikul Pakusari Jember.

3. Responden / santri

\section{DAFTAR PUSTAKA}

Ahmad, F. (2014). Hubungan Peran Pos Kesehatan Pesantren (Poskestren) Dengan Perilaku Personal Hygiene Remaja Santri Pondok Pesantren Darul Hikmah AlGhazaalie Kranjingan Kecamatan Sumbersari Kabupaten Jember . Tidak Dipublikasi .

Akmal, S. C., Semiyarti, R., \& Gayatri. (2013). Hubungan Personal Hygiene Dengan Kejadian Skabies Di Pondok Pendidikan Islam Darul Ulum, Palarik Air Pacah,
Kecamatan Koto Tangah Padang Tahun 2013 . Jurnal Kesehatan Andalas .

Ali, R. (2017). Faktor Yang Mempengaruhi Riwayat Diare Pada Pondok Pesantren . Tidak Dipublikasi .

Anorital, \& Andayasari, L. (2015). Kajian Epidemiologi Penyakit Infeksi Saluran Pencernaan Yang Disebabkan Oleh Amuba Di Indonesia. Media Litbangkes .

Depkes, R. (2007). Pedoman Penyelenggaraan Dan Pembinaan Pos Kesehatan Pesantren. Jakarta: Depkes.

Elizabeth, M. Z. (2017). Program Pengelolaan Kebersihan Lingkungan Di Pesantren. DIMAS, Volume 17, No. 1, Mei .

Hidayat, M. (2010). Problematika Kesehatan Di Pesantren (Suatu Kajian Proses Dalam Pendidikan Kesehatan Budaya Di Pesantren X). Tidak Dipublikasi .

Irmayanti. (2013). Hubungan Asupan Makanan Dan Infeksi Kecacingan Dengan Status Gizi Pada Anak Sd Inpres Bakung Kabupaten Gowa . Tidak Dipublikasikan

Notoadmojo, S. (2010). Promosi Kesehatan Dan Ilmu Perilaku. Jakarta : Rineka.

Rosmila. (2013). Sanitasi Dan Periaku Personal Hygiene Santri Pondok Pesantren Darul Abrar Kabupaten Bone Tahun 2013. Tidak Dipublikasi .

Suharmanto. (2015). PROBLEMATIKA Kesehatan Di Pesantren (Suatu Kajian Proses Dalam Pendidikan Kesehatan Budaya Di Pesantren X). Tidak Dipublikasi .

Syam, N., Gafur, A., \& Hamzah, W. (2018). Pkm Pengembangan Pos Kesehatan Pesantren 
Jurnal SainHealth Vol. 2 No. 2 Edisi September 2018

(C) Fakultas Ilmu Kesehatan Universitas Maarif Hasyim Latif Sidoarjo

p-ISSN : 2548-8333

e-ISSN : 2549-2586

(Poskestren) Di Yayasan Wakaf Umi

Pesantren Wihdatul Ulum Desa

Bontokassi, Kec. Parangloe, Kab. Gowa

Tahun 2017. Jurnal Balireso Vol. 3, No. 1,

Januari .

Zakiudin, A., \& Zhaluhiyah, Z. (2016). Perilaku

Kebersihan Diri (Personal Hygiene)

Santri Di Pondok Pesantren Wilayah

Kabupaten Brebes Akan Terwujud Jika

Didukung Dengan Ketersediaan Sarana

Prasarana. Jurnal Promoso Kesehatan

Indonesia, Volume 11 No. 2, Agustus . 